\title{
JADWAL PRAKTIKUM BERBASIS ORANGE Pi DI LABORATORIUM JURUSAN TEKNIK ELEKTRO POLITEKNIK NEGERI LHOKSEUMAWE
}

\author{
Isaruddin $^{1^{*}}$ \\ Politeknik Negeri Lhokseumawe Jurusan Teknik Elektro, Jalan Banda Aceh - Medan Lhokseumawe Km. 280.3 \\ * E-mail : Isaruddin.plp@gmail.com
}

\begin{abstract}
Abstrak
Papan informasi secara digital pada Laboratorium Jurusan Teknik Elektro memberikan informasi bagi penguna laboratorium. Makalah ini memjelaskan papan informasi praktikum yang berguna untuk mahasiswa, PLP dan dosen menggunakan alat orange Pi. Orange Pi merupakan single board komputer yang ukurannya lebih kecil dari komputer dan memiliki Micro Prosesor dan RAM. Hasil menunjukan data yang ditampilkan berjalan secara real time terkecuali input tegangan yang dibutuhkan oleh orange pi masih on. Alat orange pi harus diset kembali sesuai tanggal yang diinginkan untuk mendapatkan hasil yang sesuai. Papan jadwal praktikum menggunakan alat orange Pi sudah diaplikasikan di laboratorium Jurusan Teknik Elektro.
\end{abstract}

Kata Kunci : Jadwal Praktikum, Orange Pi,

Abstract

Digital information board at the Laboratory of Electrical Engineering provides information for laboratory users. This paper describes an useful practical information board for students, PLP and lecturers using orange Pi tool. The orange Pi tool is a single board computer whose size is smaller than a computer and has Micro Processor and RAM. The result showed that the data displayed run in real time unless the input voltage needed by orange pi was still on. To get the reliable data, the orange pi tool must be set back according to the desired date. The practical schedule board using orange Pi has been applied in the laboratory of Electrical Engineering Department.

Keywords: Practicum Schedule, Orange Pi,

\section{Pendahuluan}

Salah satu masalah manusia adalah penjadwalan mulai dari tempat kerja, sekolah, bahkan salah satunya dalam hal masalah jadwal masuk praktikum di laboratorium atau bengkel. Akhirnya dikembangkan sebuah papan agenda yang berfungsi mempermudahkan dosen ataupun mahasiswa untuk melihat jadwal dan agenda masuk dengan tampilan secara digital, tentunya alat ini lebih baik, lebih praktis dan menarik dibandingkan dengan jadwal yang biasa di gunakan yang di print dalam ukuran kertas A4 dan diharapkan bisa berguna untuk jurusan.

Data output dari alat ini yang berupa jadwal penggunaan laboratorium yang akan selalu di-update secara otomatis setiap pergantian jam perkuliahan. Maka dibuatlah sebuah alat "rancang bangun informasi jadwal praktikum berbasis orange Pi". Alat ini diharapkan bisa berguna untuk mahasiswa, PLP dan dosen jurusan teknik elektro.

Adapun tujuan yang ingin dicapai dalam makalah ni adalah :

1. Dengan membuat papan informasi jadwal praktikum dapat membantu mahasiswa, PLP dan dosen untuk bisa melihat jadwal yang di tampilkan secara digital dan selalu update secara otomatis setiap pergantian jadwal praktikum.
2. Dapat memberitahukan jadwal secara Real time (komputasi waktu nyata).

\section{Kajian Pustaka}

Flight Information Display System (FIDS) adalah suatu sistem yang berfungsi untuk menampilkan informasi jadwal penerbangan baik kedatangan pesawat (arrival) maupun keberangkatan pesawat (departure) di suatu bandar udara. Media untuk menampilkan FIDS selanjutnya menggunakan istilah jadwal penerbangan di suatu bandara yang biasanya berupa TV plasma atau juga bisa TV LED. Dalam makalah ini menjelaskan papan informasi jadwal praktikum di laboratorium Jurusan Teknik Elektro yang kinerjanya sama seperti papan informasi jadwal penerbangan yang ada di bandara pesawat, dengan menggunakan Orange PI.

\section{Orange $\mathbf{P i}$}

Orange Pi Personal Computer (PC) ini merupakan single board komputer yang mana ukurannya lebih kecil dari komputer biasa, dan bisa langsung dipakai karena di dalamnya sudah tertanam Micro Prosessor dan RAM. Kebanyakan single board komputer digunakan untuk keperluan robotika. Orange Pi PC didukung prosesor dari Alwinner H3 yang sudah 
quad-core dan disandingkan dengan pengolah grafis mali 400MP2 yang dapat memutar video resolusi hingga 4K, serta RAM. Orange Pi PC juga dilengkapi dengan soket HDMI dan AV, soket LAN, 3 soket USB 2.0, sebuah soket micro USB, pemancar infra merah, mikrofon, serta slot micro SD untuk media penyimpanannya. Selain itu, terdapat juga 40-pin yang kompatibel dengan aksesoris dari Raspberry Pi, CSI interface untuk kamera, dan LED yang menunjukan indikator power dan status pada Orange Pi ini.

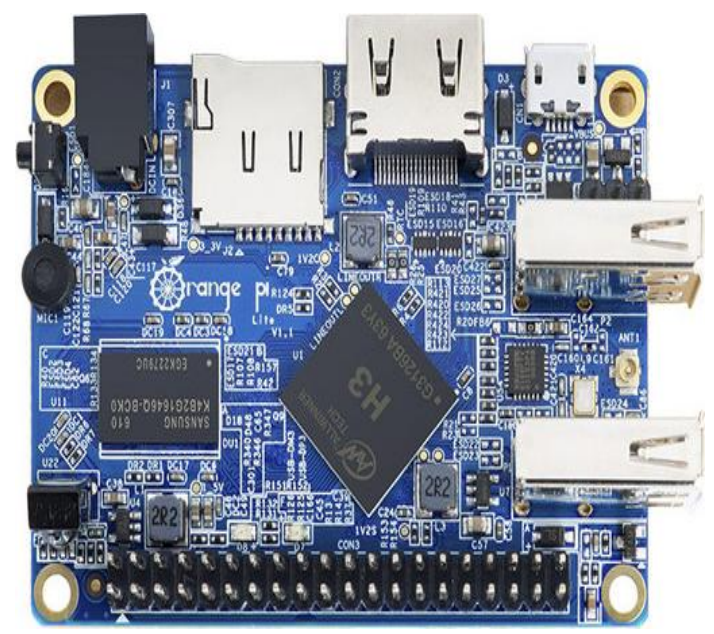

Gambar 1. Tampilan Hardware Orange Pi

$\checkmark$ CPU

- ARM Cortex-A7 Quad-Core

- 512KB L2-Cache (shared between four cores)

- 32 KB (Instruction) / 32 KiB (Data) L1-Cache per core

- SIMD NEON, VFP4

- Virtualization

- Large Physical Address Extensions (LPAE) ITB

$\checkmark$ GPU

- ARM Mali400 MP2

- Featuring 1 vertex shader (GP) and 2 fragment shaders $(P P)$.

- Complies with OpenGL ES 2.0

Memory

- DDR2/DDR2L-DDR3/DDR3L controller

- NAND Flash controller and 64-bit ECC

Display

- Integrated HDMI V1.4 with HDCP1.2 4K@30fps

- TV CVBS output

\section{VGA Port}

Konektor Video Graphics Array (VGA) adalah konektor 15-pin DE-15 tiga baris. Konektor VGA 15 pin diberikan pada, monitor komputer, komputer laptop, proyektor, dan televisi. Pada komputer laptop atau perangkat kecil lainnya, port mini VGA kadangkadang digunakan sebagai pengganti konektor VGA berukuran penuh. Meski banyak perangkat masih menyertakan konektor VGA, penggunaan VGA umumnya berdampingan dengan standar DVI. Penggunaan VGA dan DVI cepat dihapus karena konektor HDMI dan Display Port yang baru dan lebih baik.

Konektor VGA dan kabel membawa komponen analog RGBHV (sinyal merah, hijau, biru, horizontal, sync vertikal), dan data VESA isplay Data Channel (VESA DDC). Dalam versi asli pinout DE-15, satu pin dikunci dengan mencolokkan lubang konektor (Female). Ini mencegah kabel 15 pin non-VGA dihubungkan ke soket VGA. Empat pin ID monitor ID yang jarang digunakan yakni VESA DDC, mendefinisikan,.beberapa pin dan mengganti pin kunci dengan catu daya DC $+5 \mathrm{~V}$. Perangkat yang sesuai dengan standar sistem host DDC memberikan $5 \mathrm{~V} \pm 5 \%$ dan memasok minimal $300 \mathrm{~mA}$ hingga maksimum $1 \mathrm{~A}$.

Interface VGA tidak direkayasa menjadi hotpluggable (sehingga pengguna tidak dapat menghubungkan atau melepas perangkat output saat host sedang berjalan), meski dalam prakteknya hal ini bisa dilakukan dan biasanya tidak menyebabkan kerusakan pada perangkat keras atau masalah lainnya. Namun, tidak ada dalam desain yang memastikan pin ground membentuk hasil pertama atau penghentian terakhir dalam koneksi, jadi hotplugging mungkin mengenalkan lonjakan pada garis sinyal yang mungkin atau mungkin tidak dilindungi secara memadai terhadap kerusakan. Selain itu, dikarenakan ketergantungan pada perangkat keras dan lunak, deteksi monitor terkadang tidak dapat diandalkan saat memasang koneksi VGA secara hotplugging.

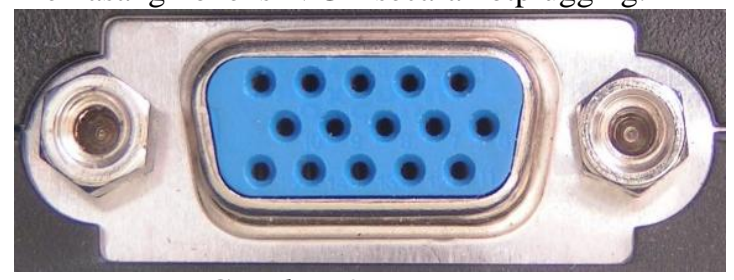

Gambar 2. VGA Port

Tabel 1. Konfigurasi Pin VGA

\begin{tabular}{ll}
\hline No. & \multicolumn{1}{c}{ Port dan Fungsi } \\
\hline 1. & Pin 1 (red) red video \\
\hline 2. & Pin 2 (green) green video \\
\hline 3. & Pin 3 (blue) blue video \\
\hline 4. & Pin 4 (IR2/RES) formerly monitor ID \\
\hline
\end{tabular}




\begin{tabular}{ll}
\hline & bit 2, reserved since E-DDC \\
\hline 5. & Pin 5 (grd) ground (Hsync) \\
\hline 6. & Pin 6 (red_rtn) red return \\
\hline No. & \multicolumn{1}{c}{ Port dan Fungsi } \\
\hline 7. & Pin 7 Green return \\
\hline 8. & Pin 8 Blue return \\
\hline 9. & $\begin{array}{l}\text { Pin } 9 \text { formerly key, now }+5 V \text { DC }, \\
\text { powers EDID } \\
\text { chip on some monitors }\end{array}$ \\
\hline 10. & Pin 10 Ground (VSync, DDC) \\
\hline 11. & $\begin{array}{l}\text { Pin 11 formerly Monitor ID bit } 0, \\
\text { reserved since E-DDC }\end{array}$ \\
\hline 12. & $\begin{array}{l}\text { Pin } 12 \text { formerly Monitor ID bit } 1, I^{2} C \\
\text { data since DDC2 }\end{array}$ \\
\hline 13. & Pin 13 Horizontal sync \\
\hline 14. & Pin 14 Vertical sync \\
\hline 15. & $\begin{array}{l}\text { Pin 15 formerly Monitor ID bit } 3, I^{2} C \\
\text { clock since DDC2 }\end{array}$ \\
\hline
\end{tabular}

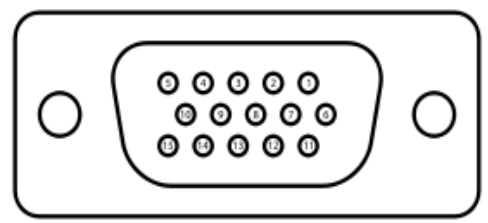

Gambar 3. Pin VGA

\section{Monitor}

Monitor merupakan salah satu perangkat keras yang digunakan sebagai penampilan output video dari komputer, dan kegunaannya tersebut tidak dapat dipisahkan dalam pemakaian suatu komputer, Monitor pun berkembang seiring dengan berkembangnya teknologi. Salah satu jenis monitor adalah Monitor Liquid Crystal Display ( LCD). Saat ini perkembangan LCD sangatlah pesat. Cara kerja monitor LCD sebagai berikut. Pada sebuah panel LCD berwarna, setiap pixel terdiri atas tiga buah cell kristal cair. Setiap ketiga cell tersebut memiliki filter merah, hijau, atau biru (Red-Green-Blue/RGB). Sinar yang melewati cell yang terfilter tersebut akan menciptakan warna yang terlihat pada LCD, namun, terkadang sistem mengirimkan arus listrik pada satu cell atau lebih tidak berjalan dengan baik. Kejadian tersebut menimbulkan adanya pixel yang gelap dan "rusak" yang sering disebut sebagai dead pixel.

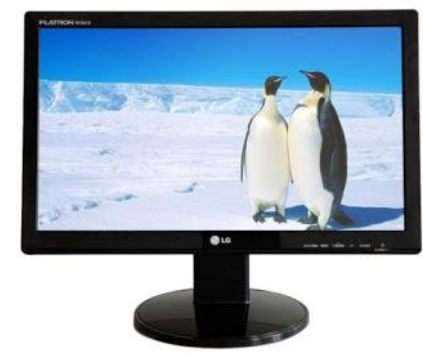

Gambar 4. Monitor LCD
Hampir semua LCD berwarna modern menggunakan sebuah transistor film yang tipis ThinFilm Transistor (TFT). TFT dikenal sebagai active matrix, untuk menghidupkan setiap cell. LCD TFT menciptakan citra yang lebih jelas, jernih dan terang. Teknologi LCD terdahulu sangat lambat, kurang efisien, dan kontrasnya sangat rendah. Teknologi matriks terdahulu, passive-matrix, mampu menampilkan teks yang jelas tetapi meninggalkan bayangan jika tampilan berubah dalam waktu cepat, sehingga tidak optimal untuk video.

Jenis lain monitor adalah Light-Emitting Diode (LED) atau dioda cahaya organik. Seperti namanya monitor jenis ini menggunakan LED sebagai komponen penghasil warna. LED menggunakan cahaya. LED menggunakan diode untuk membuat banyak vibrant dan image yang berwarna-warni. warna hitam akan menjadi benar-benar hitam, dan warna LED lebih realistis dibandingkan monitor LCD. Monitor LED memiliki kontras rasio 500,000:1, juga refresh rate yang tinggi.

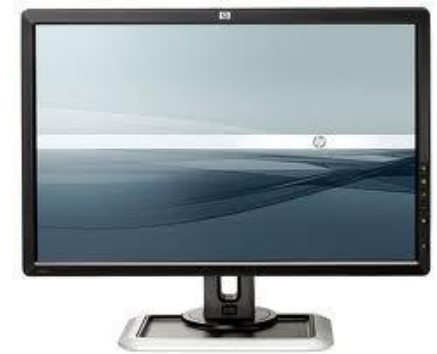

Gambar 5. Monitor LED

\section{HDMI Port}

High-Definition Multimedia Interface (HDMI) adalah salah satu antarmuka peralatan audio/video digital tanpa kompresi yang didukung oleh industri. HDMI menyediakan antarmuka antara beberapa sumber audio/video digital yang cocok, set-top box, pemutar DVD atau penerima AV serta audio digital dan/atau monitor video yang cocok, saperti televisi digital (DTV).

HDMI mendukung video standar yang lebih tinggi, ataupun definisi tinggi didukung dengan audio digital multi kanal pada kabel tunggal. Hal ini tidak tergantung pada standar DTV seperti ATSC, dan DVB(-T,-S,-C), karena semuanya merupakan enkapsulasi stream data MPEG, yang dilewatkan pada dekoder, dan keluar sebagai data video tak terkompresi, yang dapat berdefinisi tinggi. Data video ini kemudian dikodekan menjadi TMDS untuk transmisi digital melalui HDMI. HDMI juga mendukung 8 kanal audio digital tak termampatkan. Dimulai dengan versi 1.2, saat ini HDMI mendukung hingga 8 kanal audio satu bit. audio satu bit digunakan pada CD super audio. 
Konektor HDMI tipe A standar mempunyai 19 pin, sedangkan versi resolusi yang lebih tinggi disebut tipe B. Tipe B telah didefinisikan, walaupun belum digunakan secara umum. Tipe B mempunyai 29 pin, yang mampu membawa kanal video expanded untuk digunakan dengan tampilan beresolusi tinggi. Tipe B dirancang untuk mendukung resolusi yang lebih tinggi dari 1080p.

HDMI tipe A juga cocok dengan Digital Visual Interface (DVI-D) hubungan tunggal yang digunakan pada monitor komputer modern dan kartu grafik. Hal ini berarti bahwa sumber DVI dapat menggerakkan monitor HDMI, atau sebaliknya, dengan adapter atau kabel yang sesuai, akan tetapi fitur audio dan pengendalian jarak jauh HDMI-nya akan tidak tersedia. Sebagai tambahan, tanpa dukungan untuk High-Bandwidth Digital Content Protection (HDCP) pada kedua ujungnya, mutu dan resolusi video dapat diturunkan dengan sumber sinyalnya untuk mencegah pengguna dari melihat atau lebih khusus lagi merekam isi yang dilindungi. Hampir semua hubungan HDMI mendukung HDCP, sedangkan beberapa hubungan DVI tidak. HDMI tipe B cocok dengan DVI hubungan ganda yang terdahulu.

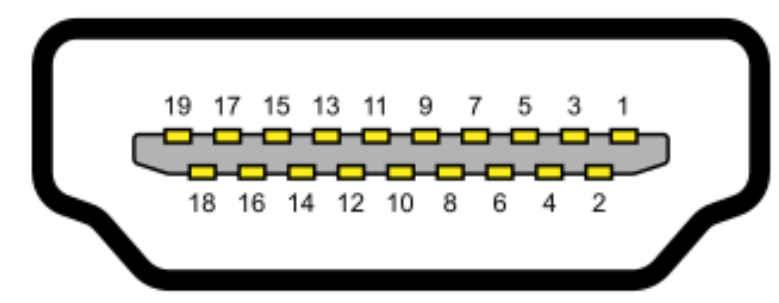

Gambar 6. Pin HDMI

Sumber : https://id.wikipedia.org/wiki/HDMI

Tabel 2. Pin Konektor HDMI

\begin{tabular}{ll}
\hline No. & \multicolumn{1}{c}{ Pin - Penetapan Sinyal } \\
\hline 1. & Pin 1 TMDS Data2+ \\
\hline 2. & Pin 2 TMDS Data2 Shield \\
\hline 3. & Pin 3 TMDS Data2- \\
\hline 4. & Pin 4 TMDS Data2+ \\
\hline 5. & Pin 5 TMDS Data1 Shield \\
\hline 6. & Pin 6 TMDS Data1- \\
\hline 8. & Pin 7 TMDS Data0+ \\
\hline 9. & Pin 8 TMDS Data0 Shield \\
\hline 10. & Pin 9 TMDS Data0- \\
\hline 11. & Pin 10 TMDS Clock+ \\
\hline 12. & Pin 12 TMDS Clock Shield \\
\hline 13. & Pin 13 CEC \\
\hline 14. & Pin 14 Persediaan N.C pada perangkat \\
\hline 15. & Pin 15 SCL \\
\hline 16. & Pin 16 SDA \\
\hline 17. & Pin 17 DDC/CEC Ground \\
\hline
\end{tabular}

\begin{tabular}{ll}
\hline 18. & Pin 18 Power $+5 \mathrm{~V}$ \\
\hline 19 & Pin 19 Hot Plug Groud \\
\hline
\end{tabular}

\section{Metode Penelitian}

Pembuatan sistem dilakukan terlebih dahulu sebelum pembuatan alat. Perancangan dimulai dari blok diagram hingga pembuatan alat. Agar papan informasi jadwal praktikum berkerja secara optimal, maka diperlukan perangkat keras sebagai berikut: Orange Pi H3 Quad-core Cortex-A7 dan konverter HDMI to VGA untuk menghubungkan antara Orange Pi ke monitor diagram blok ditunjukkan pada Gambar 7.

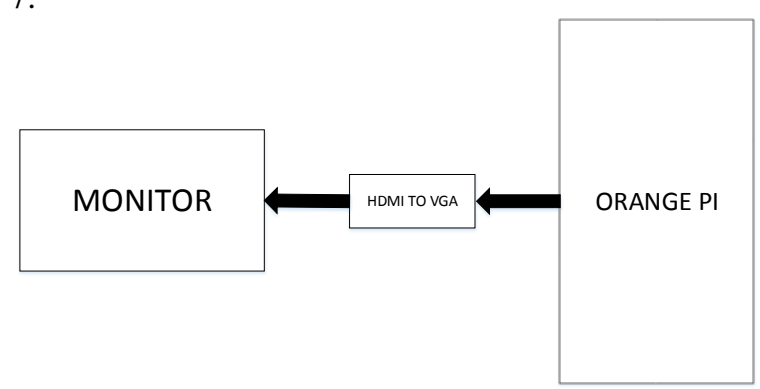

Gambar 7. Diagram blok

Fungsi-fungsi setiap blok diagram, sebagai berikut :

1. Orange $\mathrm{Pi}$ sebagai pengontrol seluruh sistem rangkaian dan menyimpan program.

2. HDMI to VGA sebagai penghubung antara monitor dengan orange pi

3. Monitor digunakan sebagai tampilan

\section{Perangkat keras Papan Informasi Praktikum}

Perancangan alat dan pembuatan rangkaian terdiri dari sebuah Orange Pi dan HDMI to VGA. Dengan adanya komponen-komponen tersebut, hasil dapat ditampilan pada monitor.

Adapun spesifikasi alat sebagai berikut;

Tabel 3. Spekasi Hardware

\begin{tabular}{ll}
\hline No. & \multicolumn{1}{c}{ Spesifikasi Hardware } \\
\hline 1. & CPU : H3 Quad-core Cortex-A7 \\
& H.265/HEVC 4K \\
\hline 2. & GPU \\
& .Mali400MP2 GPU @ 600MHz \\
& Supports OpenGL ES 2.0 \\
\hline 3. & Memory ( SDRAM) \\
& 512MB DDR3 (shared with GPU) \\
\hline 4. & Onboard Storage : TF card (Max. \\
& 64GB) / MMC card slot \\
\hline 5. & Video Outputs : HDMI \\
\hline 6. & Audio Output : HDMI \\
\hline 7. & Power Source : DC input, USB OTG \\
& input don't supply power \\
\hline 8. & USB 2.0 Ports : Two USB 2.0 HOST, \\
\hline
\end{tabular}




\begin{tabular}{ll}
\hline & one USB 2.0 OTG \\
\hline 9. & GPIO $(1 \times 3)$ pin : UART, ground. \\
\hline 10 & $\begin{array}{l}\text { Supported OS : Android Lubuntu, } \\
\text { Debian, Rasberry Pi Image }\end{array}$ \\
\hline
\end{tabular}

Tampak Alat Dalam 3 Dimensi(3D)

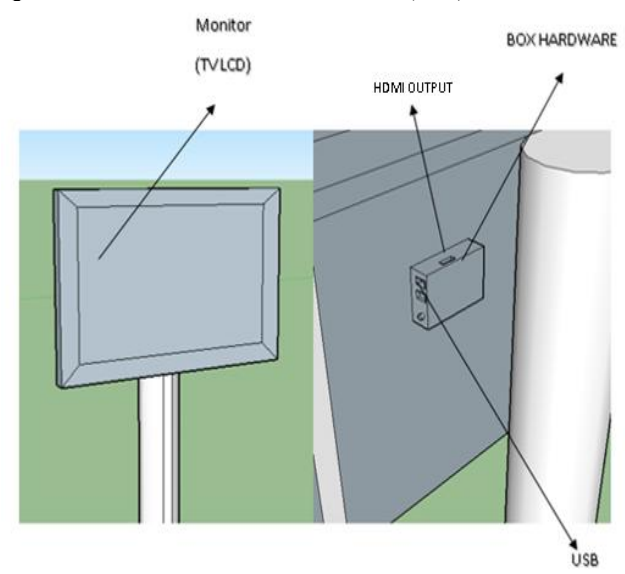

Gambar 8. Tampak alat secara 3D

Fungsi-fungsi dalam tampilan 3D

- Monitor untuk tampilan

- HDMI output sebagai tempat menghubungkan Port VGA monitor dengan HDMI to VGA

- Box hardware sebagai pelingdung sistem minimum yang rentan terhadap air dan panas

- USB sebagai memasukan data atau mengubah data

\section{Skematik Rangkaian HDMI Orange Pi}

Konverter HDMI ke VGA dibutuhkan untuk menghubungkan output HDMI dengan monitor, jika monitor belum dilengkapi HDMI.

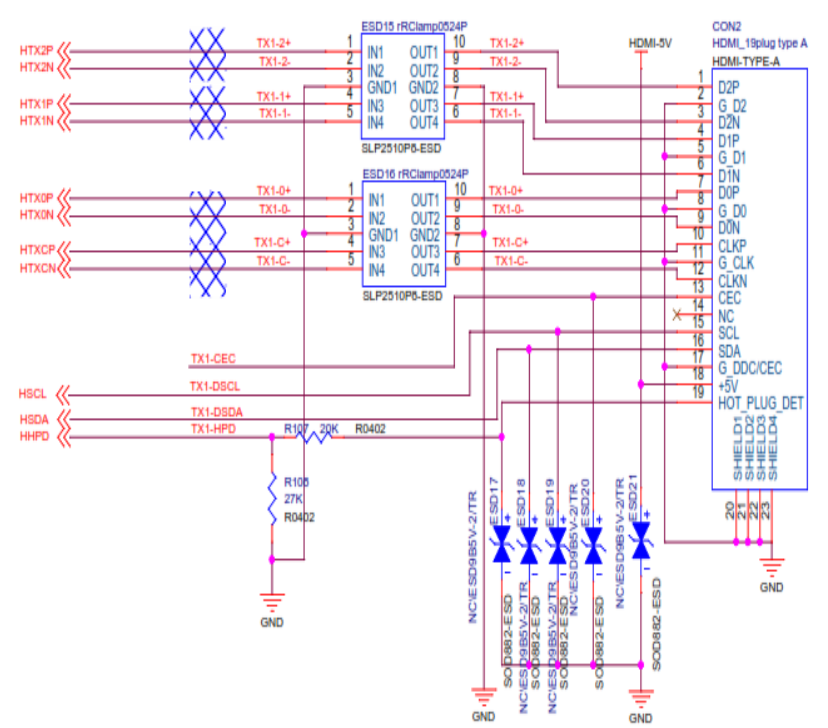

Gambar 9. Skematik rangkaian output HDMI Skematik Rangkaian USB Orange Pi

Port USB yang sudah ada pada orange pi digunakan untuk mengirim data program, yang kemudian dimasukan ke hardware (miring).

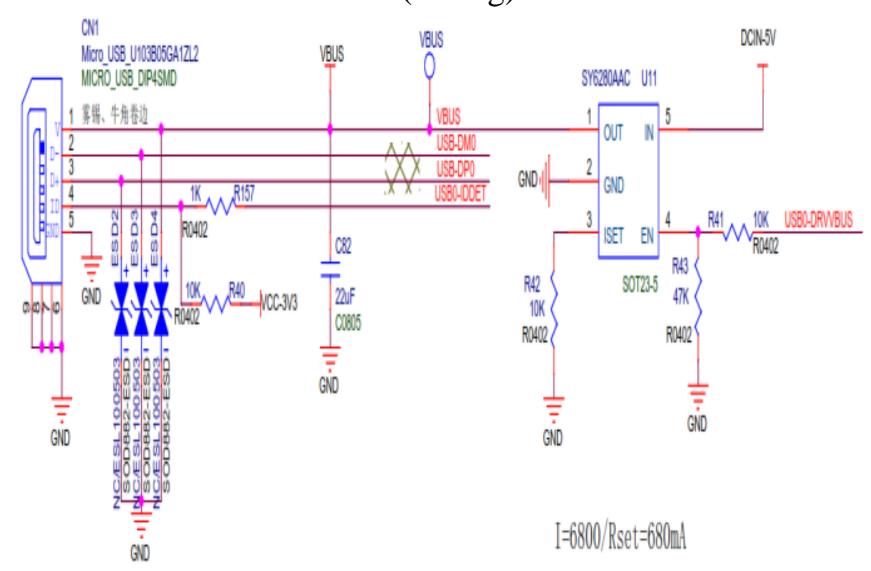

Gambar 10. Skematik rangkaian USB pada Orange Pi

\section{Skematik Rangkaian Tegangan Orange Pi}

Setiap alat elektronik selalu menggunakan tegangan yang rendah, termasuk orange Pi yang membutuhkan tegangan dibawah 5.0 volt.

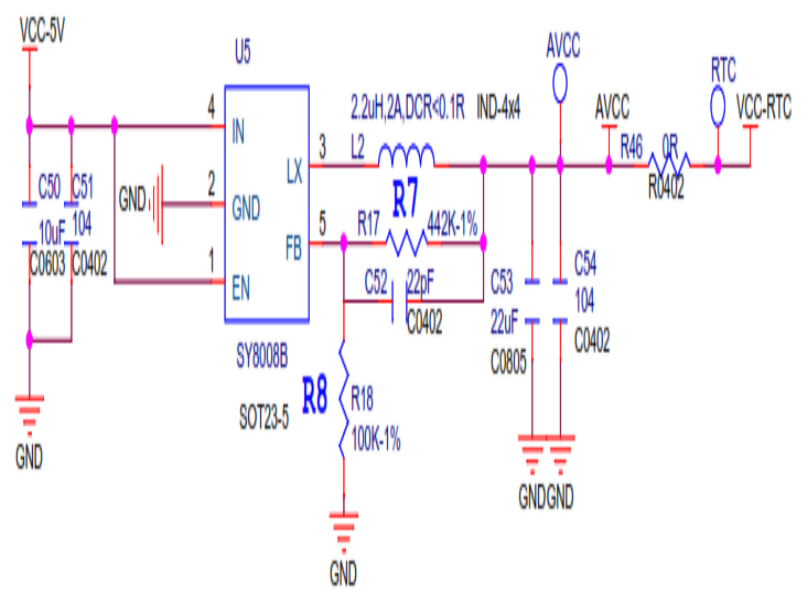

Gambar 11. Skematik rangkaian tegangan Orange Pi

\section{III.Hasil Dan Pembahasan}

Pengujian ini dilakukan untuk mengetahui sistem yang telah dibuat bekerja sesuai yang diharapkan, apabila terjadi kesalahan-kesalahan yang mempengaruh pengoperasian modul ini, maka dapat dilakukan pemeriksaan ulang. Hal ini bertujuan untuk mengecek apakah alat yang telah dibuat dapat berjalan secara benar dan sesuai dengan yang diharapkan. 


\section{Alat Dan Bahan}

Alat -alat yang dibutuhkan untuk penelitian ini adalah:

1. Oscilloscope

2. Kabel penghubung

3. Modul rangkaian yang siap diukur

\section{Sistem keseluruhan modul yang akan di ukur}

Pengujian elektronik bertujuan untuk mengetahui apakah sistem yang telah dibuat dapat berfungsi dengan baik dan sesuai spesifikasi.

\section{Pengujian Orange Pi pada Monitor}

Sistem minimum yang dipakai adalah Orange PI, 2 Volt DC yang dihubungan melalui DC Input yang sudah ada pada Orange PI, output dari HDMI digunakan konverter HDMI to VGA untuk dapat menghubungkan Orange pi dengan monitor program yang sudah dibuat. Program tersebut akan diterima dan ditampilkan oleh monitor atau TV LCD. Pengujian juga dilakukan untuk skematik rangkaian output HDMI, skematik rangkaian USB pada Orange $\mathrm{Pi}$, dan skematik rangkaian tegangan orange $\mathrm{Pi}$. Ketiga skematik bekerja dengan baik. Hal ini terlihat pada pengukuran Port VGA berfungsi dengan data pada Tabel 4, serta pengukuran juga dilakakukan dengan menggunakan Oscilloscope Gambar 12 dan 13, serta Gambar 14 tampilan jadwal praktikum.

Tabel 4. Pengukuran Port VGA

\begin{tabular}{ll}
\hline No. & \multicolumn{1}{c}{ Pin Fungsi (Hz) } \\
\hline 1. & Pin 1 RED $(50,3744)$ \\
\hline 2. & Pin 2 GREEN $(50,4292)$ \\
\hline 3. & Pin 13 Hsync $(1,50117 \mathrm{~K})$ \\
\hline 4. & Pin 14 Vsync $(52,5403)$ \\
\hline
\end{tabular}

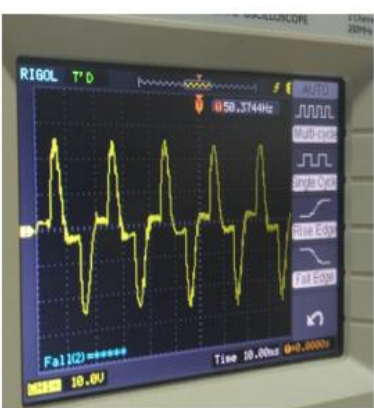

(a)

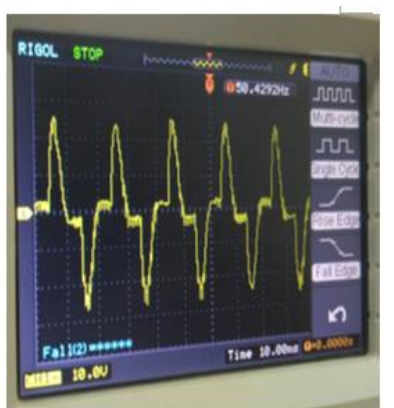

(b)
Gambar 12. a) Pengukuran oscilloscope pada pin1, b) Pengukuran oscilloscope pin 2

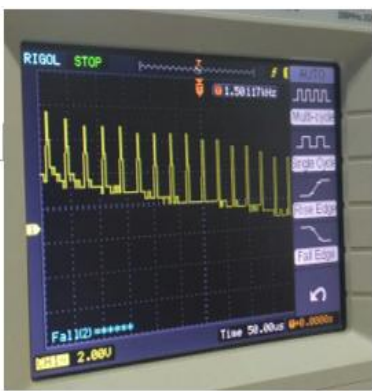

(a)

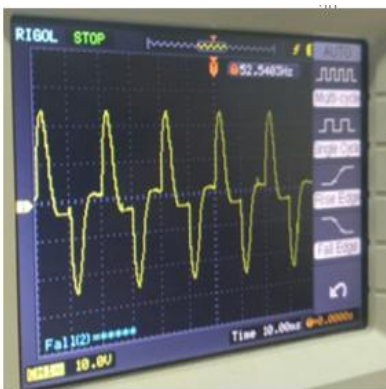

(b)
Gambar 13 . a) Pengukuran oscilloscope pada pin13, b) Pengukuran oscilloscope pin 14

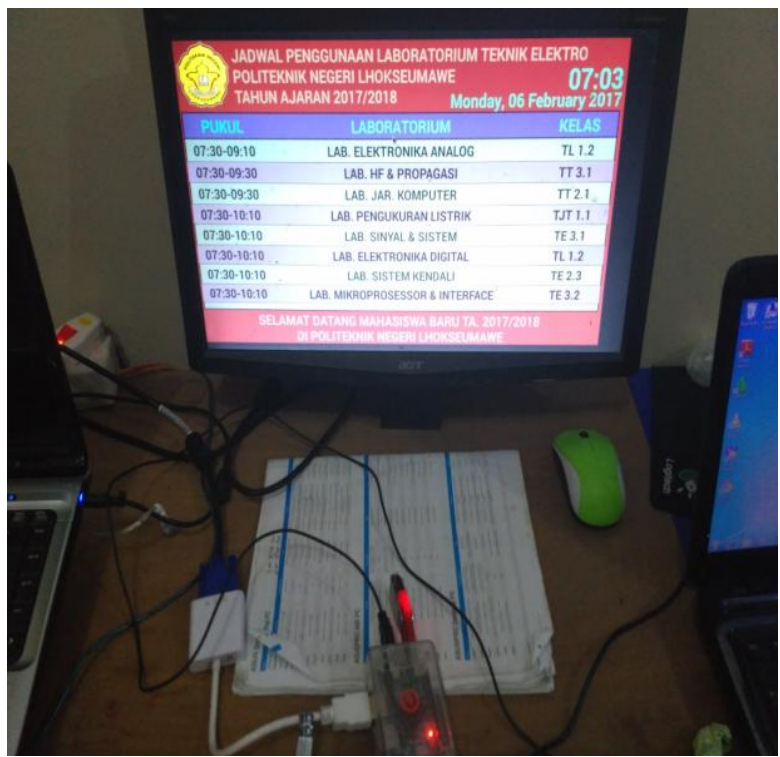

Gambar 14. Tampilan jadwal praktikum

\section{Pembahasan}

Dari hasil pengujian yang dilakukan, diamati jadwal praktikum dengan menggunakan Orange $\mathrm{Pi}$ dan berfungsi dengan baik dan ketiga skematik rangkaian dapat berfungsi dengan baik. Gambar 12 yaitu pengukuran pin 1 dan pin 2 dan gambar 13 yaitu pengukuran pin 13 dan pin 14, kedua gambar tersebut menunjukkan hasil nilai frekuensi seperti pada Tabel 4 pengukuran port VGA, sedangkan, gambar 14 menampilkan jadwal tampilan jadwal praktikum yang tampak pada monitor sebagai papan informasi digital pada Laboratorium Jurusan Teknik Elektro Politeknik Negeri Lhokseumawe.

\section{Kesimpulan}

1. Dengan menggunakan Orange Pi untuk jadwal praktikum mampu menggantikan sebuah CPU komputer.

2. Papan informasi ini dapat menampilkan jadwal pratikum untuk jurusan Teknik Elektro secara tepat, sesuai dengan jadwal praktikum yang sudah ditetapkan. 
3. Jadwal praktikum selalu update secara otomatis setiap pergantian jadwal praktikum.

\section{Ucapan Terima Kasih}

Ucapan terimakasih kepada Ketua Jurusan Teknik Elektro dan Kepala Laboratorium Jaringan Telekomunikasi Politeknik Negeri Lhokseumawe.

\section{Daftar Pustaka}

Sudjadi MT, Teori dan aplikasi Mikrokontroler pada Mikrokontroler AT89C51(2005).

Malvino, Alber paul, 1992. "Prinsip-prinsip Elektronika”.Ahli bahasa : M. Barmawi, Jakarta : Erlangga (1992).

Andi, 2011. Belajar Mirokontroler dengan bahasa C, C.V Andi OFFSET Yogyakarta (2011)

Malvino, Paul Albert. Prinsip-prinsip Elektronika Edisi kedua, Jakarta: Erlangga (2000).

Budiharto, widoo. 2003. Teknik interfacing komputer dan mikrokontroler, (2003).

PT. Elekmedia Komputindo: jakarta (2003) 